\title{
PERBANDINGAN KEKUATAN OTOT DAN MASSA OTOT ANTARA WANITA LANSIA AKTIF DAN TIDAK AKTIF BEROLAHRAGA
}

\author{
Della Hestia Suyanto ${ }^{1}$, Cindra Paskaria ${ }^{2}$, Decky Gunawan ${ }^{3}$ \\ ${ }^{1}$ Fakultas Kedokteran, Universitas Kristen Maranatha, Bandung, Indonesia. \\ ${ }^{2}$ Departemen Kesehatan Masyarakat, Fakultas Kedokteran, Universitas Kristen Maranatha, Bandung, Indonesia. \\ ${ }^{3}$ Departemen Fisiologi, Fakultas Kedokteran, Universitas Kristen Maranatha, Bandung, Indonesia.
}

\begin{abstract}
Aging is a process of slowly losing the tissue ability to maintain normal function and causing changes in muscle structure and function. Decrease in strength and muscles mass is a problem that often found in the elderly. Exercise is one of the factors that affect strength and muscle mass. This objective of the research is to compare the strength and muscle mass in elderly woman who active and not actively exercising. This study is an observational analytic study with cross sectional design analyzed by independent T-test. The research subjects were taken by purposive sampling, 20 elderly woman aged over 60 years who met the inclusion and exclusion criteria were assessed for sports activity, muscle strength, and muscle mass, so that it is obtained a sample of 13 elderlies who are active exercising and 7 elderlies who are not actively exercising. Handheld muscle strength research data was measured using a handgrip dynamometer, muscle mass was measured using the Bioimpedance Analysis (BIA) method and exercise habits were taken from the modification of Baecke Physical Activity questionnaire. The results show that the elderly who were active in exercising with a mean score of muscle strength $(10.59 \pm 3.62)$ and muscle mass $(34.22 \pm 4.62)$ were higher than those who did not exercise $(6.51 \pm 3.42)$ and $(29.81 \pm 3.39)$ with p-values of 0.020 and 0.0125 . There is a difference between strength and muscle mass in elderly woman who are active and not actively exercising.

Keywords: elderly woman, exercise, muscle mass, muscle strength
\end{abstract}

Korespondensi: Della Hestia Suyanto, Fakultas Kedokteran Universitas Kristen Maranatha. Jl. Prof. drg. Surya Sumantri, M.P.H. No. 65 Bandung, Jawa Barat, Indonesia - 40164. E-mail: sdellahestia@gmail.com 


\section{PENDAHULUAN}

Lansia adalah seseorang yang telah mencapai usia 60 tahun ke atas, menurut Peraturan Pemerintah Republik Indonesia Nomor 43 tahun 2004. ${ }^{1}$ World Health Organisation (WHO) membagi lansia menjadi 4 kelompok yaitu, usia pertengahan (middle age) adalah 45- 59 tahun, lanjut usia (elderly) adalah 60-74 tahun, lanjut usia tua (old) adalah 75-90 tahun, dan usia sangat tua (very old) di atas 90 tahun. $^{2}$ Dalam waktu 50 tahun populasi lansia di dunia akan mengalami peningkatan 3 kali lipat, dari 600 juta individu pada tahun 2000, menjadi 2 milliar pada tahun $2050 .^{3}$ Lansia di Indonesia pada tahun 2018 sekitar 24,49 juta $(9,27 \%)$ dan diperkirakan pada tahun 2045 jumlahnya meningkat menjadi 63,31 juta. Badan Pusat Statistik (BPS) memperkirakan pada tahun 2045 Indonesia akan memiliki hampir 63,31 juta lansia. ${ }^{4}$ Angka harapan hidup untuk perempuan lebih tinggi bila dibandingkan dengan laki-laki. Hal ini dapat dilihat dari jumlah lansia perempuan $(9,53 \%)$ yang lebih banyak daripada lansia laki-laki sebesar $(8,54 \%)$. Populasi lansia di Indonesia diprediksi akan terus meningkat sehingga Indonesia menjadi salah satu negara yang berstruktur tua (aging population). ${ }^{1}$

Anggaran biaya untuk perawatan lansia di Indonesia dikategorikan sangat tinggi seiring dengan peningkatan jumlah populasi lansia di Indonesia. Salah satu upaya untuk mengurangi anggaran biaya tersebut adalah dengan menerapkan gaya hidup sehat pada lansia agar terhindar dari masalah kesehatan, diantaranya dengan melakukan olahraga secara rutin. Olahraga menjadi salah satu cara yang paling murah dan mudah yang dapat dilakukan oleh semua individu, sebagai upaya untuk meningkatkan rentang hidup, kualitas hidup, mencegah perubahan struktural dan fungsional yang memburuk terutama untuk lansia. ${ }^{5}$ Olahraga yang dilakukan secara rutin dapat menghambat terjadinya proses penuaan, mencegah penyakit pada lanjut usia, dan mampu mencegah penurunan kemampuan fungsional tubuh meningkatkan massa otot sekaligus memberikan peran yang cukup besar untuk kekuatan otot. ${ }^{6}$

Perubahan akibat dari proses penuaan tersebut biasanya terjadi 50 tahun setelah kehidupan, yang ditandai dengan penurunan kekuatan kurang lebih $1,5-5 \%$ tiap tahunnya. ${ }^{7}$ Kekuatan otot tertinggi terjadi pada usia 30 tahun, dan berkurang perlahan sekitar $30-40 \%$ sampai mencapai usia 80 tahun. ${ }^{8}$ Kekuatan otot adalah kemampuan otot untuk mengerahkan gaya kontraktil maksimal terhadap resistensi dalam kontraksi tunggal. ${ }^{6}$ Proses penuaan mengubah pola serat otot dan membuat melambatnya waktu untuk berkontraksi dan kecepatan otot. Penyebab lain dari proses penuaan adalah penurunan massa otot. Massa otot dapat mengalami penurunan sebesar 3-8 \% per dekade sesudah usia 30 tahun dan setelah usia 60 tahun laju penurunan akan terjadi lebih cepat. ${ }^{5,8}$

Hasil penelitian sebelumnya terhadap 52 orang lansia wanita yang dibagi kelompok lansia aktif dan tidak aktif berolahraga di Semarang menyatakan adanya perbedaan kekuatan otot pada lansia wanita yang aktif dan tidak aktif berolahraga. ${ }^{9}$ Tujuan dilakukan penelitian ini adalah untuk mengetahui perbandingan kekuatan (genggam) dan massa otot antara lansia yang aktif dan tidak aktif berolahraga.

\section{METODE}

Penelitian ini dilaksanakan di Panti Wredha Karitas Cimahi dan Panthi Wredha Kudus yang terdiri dari 13 lansia perempuan yang aktif berolahraga dan 7 lansia tidak aktif berolahraga. Subjek penelitian dipilih dengan metode purposive sampling yang sesuai dengan kriteria inklusi yaitu, lansia perempuan berusia 60 tahun keatas, dapat berkomunikasi secara verbal serta sukarela, kooperatif dan bersedia menjadi subjek penelitian dengan menandatangani informed consent. Metode penelitian ini adalah observasional analitik dengan rancangan cross sectional. Analisa data menggunakan uji-T tidak berpasangan dengan $\alpha=$ 0,05 .

Prosedur penelitian dimulai dengan menjelaskan maksud dan tujuan penelitian serta memastikan subjek penelitian bersedia berpartisipasi dan telah mendatangani informed consent. Penelitian dilanjutkan dengan melakukan tanya jawab terhadap berdasarkan kuesioner modifikasi aktivitas fisik (Baecke) untuk menentukan apakah lansia termasuk kelompok yang aktif atau tidak aktif berolahraga. Kekuatan otot genggam lansia diukur menggunakan handgrip dynamometer dan massa otot diukur menggunakan timbangan digital dengan metode Bioimpedance Analysis (BIA). Penelitian ini telah mendapatkan ijin dari oleh Komisi Etik Penelitian Fakultas Kedokteran Universitas Kristen Maranatha dengan surat keputusan No: 054/KEP/VI/2020.

\section{HASIL}

Pada tabel 1 dapat dilihat bahwa hasil uji-T tidak berpasangan perbandingan kekuatan otot genggam lansia perempuan yang aktif dan tidak aktif berolahraga menunjukkan hasil yang signifikan ( $p=0,0125)$. Hal ini menunjukkan adanya perbedaan yang signifikan antara rerata kekuatan otot genggam lansia perempuan yang aktif berolahraga dengan yang tidak aktif. 
Rerata kekuatan otot genggam pada lansia perempuan yang aktif berolahraga lebih tinggi daripada lansia perempuan yang tidak aktif berolahraga

Pada tabel 2 dapat dilihat bahwa hasil uji-T tidak berpasangan perbandingan massa otot lansia perempuan yang aktif dan tidak aktif berolahraga menunjukkan hasil yang signifikan $(p=0,020)$. Hal ini menunjukkan adanya perbedaan yang signifikan antara rerata massa otot lansia perempuan yang aktif berolahraga dengan yang tidak aktif. Rerata massa otot pada lansia perempuan yang aktif berolahraga lebih tinggi daripada lansia perempuan yang tidak aktif berolahraga.

Tabel 1. Analisis Perbandingan Rerata Kekuatan Otot Genggam

\begin{tabular}{lcrrrr}
\hline \multirow{2}{*}{ Aktivitas Olahraga } & \multicolumn{4}{c}{ Kekuatan Otot Genggam (kg) } & \multirow{2}{*}{ p-value } \\
\cline { 2 - 5 } & N & Min. & Maks. & Rerata \pm SD & \\
\hline Aktif & 13 & 5,9 & 15,4 & $10,59 \pm 3,62$ & \multirow{2}{*}{0,0125} \\
Tidak Aktif & 7 & 2,0 & 12,3 & $6,51 \pm 3,42$ & \\
\hline
\end{tabular}

Tabel 2. Analisis Perbandingan Rerata Massa Otot Antar Lansia

\begin{tabular}{lccccc}
\hline \multirow{2}{*}{ Aktivitas Olahraga } & \multicolumn{4}{c}{ Massa Otot $(\mathbf{k g})$} & \multirow{2}{*}{ p-value } \\
\cline { 2 - 5 } & N & Min. & Maks. & Rerata \pm SD & \\
\hline Aktif & 13 & 29,1 & 41,6 & $34,22 \pm 4,62$ & \multirow{2}{*}{0,020} \\
Tidak Aktif & 7 & 26,5 & 33,4 & $29,81 \pm 3,39$ &
\end{tabular}

\section{DISKUSI}

Perbandingan Kekuatan Otot (kg) Antara Lansia Perempuan Aktif dan Tidak Aktif Berolahraga

Penelitian ini menunjukkan bahwa rerata kekuatan otot genggam pada lansia perempuan yang aktif berolahraga lebih tinggi daripada lansia perempuan yang tidak aktif berolahraga. Hal ini sesuai dengan penelitian yang dilakukan oleh Gheby et al. (2010) di Semarang terhadap 56 lansia perempuan didapatkan bahwa hasil perbandingan kekuatan otot genggam lansia yang aktif berolahraga lebih besar bila dibandingkan lansia yang tidak aktif berolahraga. Penelitian tersebut membuktikan bahwa pada kelompok lansia yang aktif berolahraga memiliki kekuatan otot genggam yang cukup dengan rerata $21,1 \mathrm{~kg}$, sedangkan pada kelompok tidak aktif berolahraga terdapat $53,8 \%$ lansia dengan kekuatan otot genggam yang dikategorikan sangat kurang dengan rerata $17,1 \mathrm{~kg}$. Lansia yang tergolong aktif berolahraga cenderung memiliki kekuatan otot genggam yang lebih baik dibandingkan yang tidak aktif. ${ }^{9}$

Olahraga menyebabkan otot mampu menerima oksigen yang cukup pada saat terjadi kontraksi otot. Olahraga yang dilakukan secara rutin dan teratur akan meningkatkan kekuatan otot dan memperlambat proses penuaan. Semakin lansia aktif berolahraga, otot akan menjadi lebih besar dan bila sebaliknya maka otot akan menjadi atrofi. Hal itu disebabkan karena otot sangat responsif terhadap aktivitas yang dilakukan. Saat terjadi kontraksi otot maka sintesis protein kontraktil otot akan bekerja jauh lebih cepat dibanding dengan proses penghancuran. Hal tersebut akan membuat miofibril mengandung filamen aktin dan miosin yang terus bertambah banyak jumlahnya. Miofibril akan terus memecah di setiap serat otot untuk terus membentuk miofibril yang baru. Semakin meningkat jumlah miofibril menyebabkan serat otot bertambah besar, terutama untuk serabut otot tipe I dan II dan sekaligus meningkatnya sistem metabolisme fosfagen, fosfokreatin, dan ATP. Peningkatan dari ketiga sistem metabolisme tersebut menyebabkan peningkatan sistem metabolisme anaerob dan aerob, yang selanjutnya akan terjadi peningkatan energi dan kekuatan otot. ${ }^{9,10}$

Lansia yang tergolong tidak aktif berolahraga akan mempercepat proses penuaan. Kekuatan otot mengalami proses reduksi yang disebabkan oleh penurunan sintesis protein, dan penurunan jumlah serabut otot sehingga terjadi atrofi. Selama proses penuaan lansia akan terjadi penurunan serabut otot sebesar $40 \%$ yang dimulai sejak usia 20 sampai 80 tahun. ${ }^{11}$ Hal tersebut masih dapat dicegah dengan aktivitas olahraga, seperti penelitian yang dilakukan oleh Titan et al. (2020) terhadap 203 lansia di Surabaya dengan uji Chi-square yang membuktikkan bila terdapat korelasi positif antara kekuatan otot dan aktivitas fisik dengan hasil $p=$ 0,001 . Semakin tinggi skor aktivitas yang dilakukan maka semakin meningkat pula kekuatan ototnya. ${ }^{12}$ Penelitian yang dilakukan Lauretani et al. (2003) membuktikkan bila kekuatan otot genggam dapat mewakili kekuatan otot yang lain. Pengukuran kekuatan otot genggam dapat menjadi salah satu alternatif untuk mendeteksi penurunan kekuatan otot pada lansia. Pada penelitian tersebut dilakukan pengukuran kekuatan otot pada ekstremitas atas dan 
bawah yang memiliki hasil serupa. Temuan tersebut menggambarkan bahwa gambaran penurunan kekuatan otot pada lansia terjadi secara keseluruhan pada seluruh tubuh. Handgrip dynamometer yang memiliki banyak kelebihan seperti, mudah, murah, sederhana dan praktis banyak digunakan untuk pengukuran otot. ${ }^{13}$ Penelitian ini juga sejalan dengan penelitian yang dilakukan oleh Gurdani Yogisutanti pada tahun 2018 di Bandung terhadap 34 lansia dengan metode quasi experimental dan rancangan pretest-posttest nonequivalent control group design. Hasil penelitian tersebut menunjukkan bahwa kekuatan otot lansia sebelum senam memiliki kekuatan otot yang lebih rendah dan sesudahnya sebagian besar responden memiliki kekuatan otot yang lebih tinggi. Senam Tai Chi memiliki pengaruh terhadap kekuatan otot dengan hasil uji statistik $p$-value sebesar $0,000 \leq \alpha(0,05)$. Semakin rutin senam dilakukan maka kekuatan otot pada lansia akan semakin membaik, sebab senam Tai Chi adalah salah satu aktivitas fisik yang dapat menangani gangguan pada muskuloskeletal. ${ }^{14}$

\section{Perbandingan Massa Otot (kg) Antara Lansia Perempuan Yang Aktif Dan Tidak Aktif Berolahraga}

Penelitian ini menunjukkan bahwa rerata massa otot pada lansia perempuan yang aktif berolahraga lebih tinggi daripada lansia perempuan yang tidak aktif berolahraga. Hal ini sesuai dengan penelitian yang dilakukan oleh Neves et al. (2018) terhadap 387 lansia di Brazil dengan studi crosssectional yang mengatakan jika massa otot memiliki korelasi yang positif terhadap aktivitas fisik dengan hasil $p<0,01$. Pengukuran massa otot dapat dikaitkan dengan cacat fungsional di masa yang akan mendatang pada lansia. Pengukuran massa otot dapat diandalkan sebagai salah satu strategi yang hemat biaya untuk pencegahan proses penuaan. Melakukan aktivitas yang rutin dan teratur dapat meminimalkan kecacatan, meningkatkan kemandirian lansia dan kinerja fungsional. Semakin sering lansia beraktivitas atau olahraga maka massa otot yang dimiliki lansia akan lebih tinggi daripada lansia yang tidak berolahraga. ${ }^{15}$

Namun, hal tersebut tidak sejalan dengan penelitian yang dilakukan oleh Titin et al tahun 2020 terhadap 203 lansia di Surabaya dengan metode Chisquare yang mengatakan jika tidak ada hubungan antara massa otot dengan aktivitas lansia. Hasil penelitian tersebut adalah $p=0,517(\mathrm{p}>0,05)$ yang menunjukkan tidak ada perbedaan yang signifikan. Dijelaskan pada penelitian bahwa perubahan massa otot hanya mempengaruhi sekitar 5\% dari total kekuatan otot. Perbedaan hasil penelitian ini dapat disebabkan karena aktivitas lansia dinilai berdasarkan Short Physical Performance Battery (SPPB) yang merupakan salah satu tes untuk mengevaluasi keseimbangan, kecepatan, berjalan, kekuatan, dan ketahanan. ${ }^{12}$

Olahraga juga diyakini mampu meningkatkan tampilan fisik seseorang, yaitu massa otot yang lebih besar. Meningkatnya massa otot disebabkan karena adanya rangsangan dari luar berupa olahraga atau aktivitas fisik. Olahraga yang dilakukan secara rutin dan teratur akan meningkatkan sintesis protein dan memperlambat penghancuran. Melalui proses tersebut, filamen aktin dan miosin di dalam miofibril bertambah jumlahnya sehingga massa otot akan bertambah. $^{10,16}$

Massa otot akan mengalami penurunan sebanyak 1-2\% setelah melewati usia 50 tahun. Akan tetapi penurunan massa otot tersebut dapat dicegah dengan melakukan olahraga secara rutin dan teratur. Massa otot dikatakan memiliki peran utama dalam penurunan kekuatan otot terkait dengan usia. Proses penuaan yang tidak diatasi dengan olahraga menyebabkan serabut otot tipe II menurun jumlahnya dan terjadi peningkatan sitokin proinflamasi, yang diketahui, selama proses penuaan berlangsung terjadi peningkatan sitokin pro inflamasi. $^{12,17}$

Penelitian ini juga sejalan dengan penelitian yang dilakukan oleh Shu Nishiguchi et al. (2014) terhadap 272 lansia perempuan di Jepang dengan hasil lansia yang tergolong dalam kelompok yang tidak aktif secara fisik memiliki penurunan yang signifikan pada massa otot di usia tua dibandingkan mereka yang aktif secara fisik dan hasil $p$-value yang diperoleh sebesar $p<0,01$. Oleh karena itu, aktivitas fisik yang dilakukan oleh lansia mampu dikaitkan dengan peningkatan massa otot di usia tua. $^{18}$

Penelitian yang dilakukan oleh Chen et al. (2013) di USA terhadap 2,647 lansia memberikan simpulan bahwa massa otot dan kekuatan otot saling berkolerasi tergantung dari usia dan jenis kelamin. Hasil penelitian menunjukan jika kekuatan dan massa otot memiliki hasil $p<0,001$ yang menyatakan adanya hubungan yang signifikan. Penelitian tersebut menilai hubungan keduanya pada lansia dan ditemukan jika massa otot menjelaskan sekitar $13 \%$ kekuatan otot. ${ }^{19}$ Selain itu penelitian oleh Cledir et al. (2019) dengan sampel 1,609 lansia di Brazil membuktikkan bila kekuatan otot genggam berhubungan secara langsung dengan massa otot dengan hasil $p<0,05 .{ }^{20}$

Keterbatasan penelitian ini adalah tidak dibahasnya faktor-faktor yang kemungkinan berpengaruh terhadap kekuatan dan massa otot 
seperti usia, asupan protein, status nutrisi, vitamin D, sistem endokrin (GH, IGF-1), dan hormonal (testosteron), dan lain-lain. Penelitian juga ini

\section{SIMPULAN}

Terdapat perbedaan kekuatan otot (genggam) antara lansia perempuan yang aktif dan tidak aktif berolahraga. Terdapat perbedaan massa

\section{PENDANAAN}

Penelitian ini tidak didanai oleh sumber hibah manapun.

\section{KONFLIK KEPENTINGAN}

Tidak ada potensi konflik kepentingan. dilaksanakan pada saat pandemi Covid-19 sehingga jumlah subjek yang diteliti tidak banyak.

otot antara lansia perempuan yang aktif dan tidak aktif berolahraga.

\section{DAFTAR PUSTAKA}

1. Kemenkes RI. Analisis Lansia di Indonesia. Pus data dan Inf Kementeri Kesehat RI. 2017.

2. Nugroho. Keperawatan Gerontik dan Geriatrik. Jakarta:EGC. 2008.

3. Riviati N, Setiati S, Laksmi PW, Abdullah M. Factors Related with Handgrip Strength in Elderly Patients. Acta Med Indones. 2017.

4. Badan Pusat Statistik. Penduduk lanjut usia. Susenas. 2010.

5. Holloszy JO. The biology of aging. Mayo Clin Proc. 2000.

6. Makino K, Ihira H, Mizumoto A, Shimizu K, Ishida T, Furuna T. Associations between the settings of exercise habits and health-related outcomes in community-dwelling older adults. J Phys Ther Sci. 2015.

7. Keller K, Engelhardt M. Strength and muscle mass loss with aging process. Age and strength loss. Muscles Ligaments Tendons J. 2013.

8. Manini TM, Clark BC. Dynapenia and aging: An update. Journals Gerontol - Ser A Biol Sci Med Sci. 2012.

9. Kekuatan Genggam pada Lansia Wanita Aktif dan Tidak Aktif Berolahraga. MEDIA Med Indones. 2012.

10. Guyton and Hall. Guyton dan Hall Buku Ajar Fisiologi Kedokteran. Elsevier, Singapore. 2014.

11. Kamo T, Nishida Y. Direct and indirect effects of nutritional status, physical function and cognitive function on activities of daily living in Japanese older adults requiring long-term care. Geriatr Gerontol Int. 2014;14(4):799-805.

12. Kristiana T, Widajanti N, Satyawati R. Association between Muscle Mass and Muscle Strength with Physical Performance in Elderly in Surabaya. Surabaya Phys Med Rehabil J. 2020;2(1):24.
13. Lauretani F, Russo CR, Bandinelli S, Bartali B, Cavazzini C, Di Iorio A, et al. Age-associated changes in skeletal muscles and their effect on mobility: An operational diagnosis of sarcopenia. J Appl Physiol. 2003;95(5):1851-60.

14. Yogisusanti G, Ardayani T, Simangunsong DSU. Jph recode vol. 1 no. 2 (2018). Jph Recode Vol 2 No 1. 2018;2(1):1-7.

15. Neves T, Fett CA, Ferriolli E, Crespilho Souza MG, dos Reis Filho AD, Martin Lopes MB, et al. Correlation between muscle mass, nutritional status and physical performance of elderly people. Osteoporos Sarcopenia. 2018;4(4):145-9.

16. Nasrulloh A. Progam Latihan Body Building dapat Meningkatkan Massa Otot Mahasiswa IKORA FIK UNY. Progam Latih Body Build dapat Meningkat Massa Otot Mhs IKORA FIK UNY. 2012;2(2).

17. Halberstadt.HHS Public Access. Physiol Behav. 2017;176(5):139-48.

18. Nishiguchi S, Yamada M, Kajiwara Y, Sonoda T, Yoshimura K, Kayama $\mathrm{H}$, et al. Effect of physical activity at midlife on skeletal muscle mass in old age in community-dwelling older women: A cross-sectional study. J Clin Gerontol Geriatr. 2014;5(1):18-22.

19. Chen L, Nelson DR, Zhao Y, Cui Z, Johnston JA. Relationship between muscle mass and muscle strength, and the impact of comorbidities: A population-based, Cross-sectional study of older adults in the United States. BMC Geriatr. 2013;13(1).

20. Amaral CA, Amaral TLM, Monteiro GTR, Vasconcellos MTL, Portela MC. Hand grip strength: Reference values for adults and elderly people of Rio Branco, Acre, Brazil. PLoS One. 2019;14(1):1-13. 